Although he was a good systematist, Regan never mistook the minutiæ of taxonomy for an end in themselves, and his outlook is well summarized in the following quotation from his address on "Organic Evolution" before Section D (Zoology) of the British Association in 1925: "Every good systematist must feel some satisfaction when he has written a diagnosis that is diagnostic, or has made a key that will work ; but this satisfaction is small compared with that which he feels when he has reason to think he has settled the position of some doubtful form, or has discovered the origin of a group and the lines of evolution within it. The main interest of systematic work lies in the fact that it is a study of the results of evolution, and that from such a study one may hope to get some light on the meaning of evolution".

Regan found in the fishes ample scope for his energies, but his interests extended beyond, and especially into other vertebrate groups. His interest in the geographical distribution of animals led him to suggest to other specialists lines of research on the interrelationships of frogs and the classification of mammals. He was convinced, moreover, that false ideas were prevalent as to the origin and classification of the primates, including the ancestry of man, and in 1930 he published a preliminary statement of his views. He followed this by an elaborate investigation into the structure and relationships of insectivores and lemurs, and left unfinished manuscripts and drawings which it is greatly to be hoped will be put into order and published. Of recent years, too, he had embarked on a general classification of the fishlike vertebrates, and, to clear up a doubtful point, had undertaken an investigation of some fossil forms. This paper also was left unfinished.

In addition to his scientific work, Regan performed important services for the British Museum (Natural History) as keeper of zoology and director. His first duty on taking the directorship was to give evidence before the Royal Commission on Museums, and as a result of this the Commission recommended increases of staff and of buildings. The increase in staff, though delayed, was finally accomplished, but the financial crisis of 1931 interfered with the plans for building to such an extent that the War found them still only partly carried out. It is sometimes thought that Regan had little interest in the exhibition side of the Museum. This was not so, but his large-scale ideas were bound up with the new building plans, and were never even put on paper.

Regan had the gift of lucid expression, founded on clear and concentrated thinking, and he enjoyed talking on a subject that interested him. He was a member of the Royal Society Dining Club and often entertained his fellow "royal philosophers" over their port with an account of his latest discovery, illustrated by specimens and drawings. Many an impromptu lecture, which would have delighted a class of students, has been reserved for my unworthy ears at South Kensington, illustrated by drawings on the back of an envelope or an empty cigarette packet.

Tate Regan was an honorary fellow of his College, received the degree of D.Sc. honoris causa from the University of Durham, and was Academico Honorario of the University of La Plata. He was a foreign member of the Royal Danish Academy, of the American Academy of Arts and Sciences, and of the American Society of Ichthyologists and Herpetologists; the Geoffrey de St. Hilaire Medal was awarded to him by the Société Nationale d'Acclimatation de France.

Regan's outstanding qualities were generosity and frankness, which endeared him to his friends, and an enthusiasm and energy which made him, like the sprinter he was in his youth, go all out for some desired objective, and left him the victim of a too severe disappointment if it failed him. He was a keen gardener and enjoyed watching a good game of football or an athletic contest. His friends mourn a rare and stimulating companion.

Sincere sympathy goes out to Mrs. Regan and their four children, one of whom is now a prisoner of war.

E. Trewavas.

\section{Dr. Nikola Tesla}

Nikola Tessa, who died on January 7, was born in 1857 at Smiljan in Croatia. His father, a Serb, was a clergyman of the Greek Church; his mother is remembered as very inventive and is credited with making improvements in churns, looms and other rural machinery. Nikola, while at school, began to make electrical experiments, and finished his formal education in the engineering faculty of the Graz Polytechnic School. After a period in the Government telegraph department at Budapest, he joined the Edison concern in Paris and went to the United States about 1883. Here he worked under Edison for a time, but soon set up his own firm for the manufacture of arc lighting plant.

At this period the applications of electric power in industry were effected mainly by direct current, but many inventors were attacking the problem of making motors suitable for use with alternating current. Tesla in the United States and Ferraris in Italy each published in 1888 the results of several years of independent work on motors utilizing rotating magnetic fields produced by two-phase currents. Both inventors envisaged machines in which the rotor is propelled asynchronously by means of currents induced in it by the rotating field, and Tesla described also motors in which the rotor is pulled round in synchronism with the rotating field. Neither type need employ brushes or commutators. These rotatingfield motors, together with the introduction of polyphase currents, proved to be the solution of the problem of using alternating current in factories. In addition, by 1890, Tesla also invented methods of starting and running motors on single-phase current. His designs were so sound that his larger machines attained efficiencies of 95 per cent. Having completed his task, he disposed of his patents to the Westinghouse Company and dropped the subject.

Hertz's work was directing attention to highfrequency alternating currents, so Tesla turned to the problem of generating these currents on an engineering scale. First he designed and built a succession of alternators, and by 1891 attained a frequency of 30,000 eycles per second. He studied the properties of these currents in circuits possessing distributed inductance and capacitance, and developed tuned coupled circuits for enhancing their voltage by resonance. For higher frequencies he employed the discharge of condensers through induction coils, obtaining big powers by aid of rotating dischargers or magnetic blow-outs at the spark gap. On coupling the primary circuit to a resonant secondary circuit comprising metal areas, large flaming and streaming ionization currents were obtained in air and in Geissler tubes. Ionic bombardment was observed to 
produce brilliant phosphorescence, and sometimes fusion, of solid matter.

But Tesla's main purpose was the transmission of power and messages across space. In 1892 and 1893 he developed his scheme. High-frequency power was to be led to a large antenna consisting of an elevated metal area connected by a vertical wire to a large metal plate buried in the earth. The receiving antenna was to be equal in every respect. The figure in the Journal of the Franklin Institute shows the source of oscillations connected into the vertical wire near the earth at the sending station, and the receiving apparatus in the corresponding place at the receiving station. He did not patent the antenna. Tesla states his belief that the electrical oscillations will be propagated along the surface of the earth and that they may be assisted by an upper canducting layer of the atmosphere - this is eight years before Heaviside and Kennelly. Tesla had thus supplied, two years before wireless began its commercial career, all the elements of both spark and continuous wave sending stations. For the receiving station the Lodge or Branly coherer was already available for spark telegraphy, but Tesla concentrated on continuous waves because he was more interested in the transmission of power than in the transmission of messages. After building one or two small stations, he started in 1897, at his own expense, a station of 200 kilowatts in Colorado. From this point in 1899 he transmitted power enough to light a lamp at $30 \mathrm{~km}$. For the reception of continuous wave signals he invented the interrupter device known as a ticker, which was employed by others for the next dozen years, and from the Colorado station received signals at a distance of $1,000 \mathrm{~km}$. Later, his form of antenna, his rotating discharger, and his tuned transformer were used successfully by many others at spark stations in every country.

Space limits this survey to a few of the now things which Tesla's creative imagination and constructive genius gave to the world. His other inventions include pyro-magnetic generators, thermo-magnetic motors, unipolar dynamos, meters, lamps, mechanical vibrators of huge power and a variety of instruments. Some seven hundred patents stand in his name, mostly taken out before he was fifty years of age. Apparently his method of work was to state a problem, devise solutions, build machines and file a patent specification or, possibly, read a paper to a technical society. Then he would start on a new problem. It happened that one of his subjects, high-frequency discharge, made a brilliant display, and he was persuaded to lecture upon it several times. The demonstrations were perfect and very showy; consequently sober folk concluded that Tesla was somewhat of a showman. This is quite wrong. Throughout his long life of eighty-five years, Tesla seldom directed attention to his own successes, never wrote up again his old work, and rarely claimed priority though continually pirated. Such reserve is especially striking in a mind so rich in creative thought, so competent in practical achievement.

\section{W. H. Eccles.}

\section{Dr. A. L. Lowell}

OF the two late presidents of Harvard, Eliot and Lowell, it was said that Eliot found Harvard a college and built upon it a university, while Lowell found a university and unearthed its college. Eliot developed great post-graduate schools, from medicine to business administration ; but his free elective system for undergraduates left the college almost spineless. It was for his successor to revalue the meaning of a B.A. degree, and he did.

The chief monument of Lowell will be his scheme of concentration (reading one main subject) and his general examination (final schools). Anglophile in nothing so much as in education, he had always approved of this method, nearly identical with that of Oxford and Cambridge, but had to watch the previous regime spare the rod and spoil the undergraduate. In the last decade of Eliot's reign, most pupils used to scoff at honours; in the last decade of Lowell's, the tendency was to scoff at those unequal to reading for them.

The second great change under Lowell was likewise of British pattern. He broke up an unwieldy university into colleges, again like Oxford and Cambridge. Long a cherished plan of his, he lacked funds for it, until one day about fifteen years ago a stranger called at the President's office. Lowell, in the midst of a busy morning, almost did not see the caller-a certain Mr. Harkness. "If," said the stranger, "you suddenly had a lot of money given you-let us say millions-for the university, what would you like to do with it ?" Lowell actually produced a set of blue-prints from a drawer. "Build separate colleges," said he promptly. "Exactly my idea," responded Harkness. "Yale, where I come from, has declined such a gift. Will you take it, and how much do you need ?" The result was the seven 'Harvard Houses' -built either entirely new or to include conversion of several hostels already in use--at the cost of $3 \frac{1}{2}$ millions sterling. (Yale then changed its mind, whereupon Harkness cheerfully donated enough more to Yale for a similar project. It was Harkness funds, of course, which also came later to Great Britain for the Commonwealth Fellowships and for the Pilgrim Trust.)

The third milestone in the presidency of Lowell was once more inspired by the example of England. $\mathrm{He}$ founded in Harvard the Society of Fellows, an adaptation of All Souls, Oxford. Under this foundation-the funds said to have been given by Lowell, himself a wealthy man-a committee of senior fellows, members of staff in Harvard, elect each year eight junior fellows, graduates of any American university of standing, for postgraduate research. These fellowships yield enough to cover all expenses of the holder, and are renewable (from three to six years) until his specific problem of research is completed. He has the utmost freedom, being not required to work for a degree. Junior fellows live in the various 'Houses', and in time may be offered appointments to the staff:

As the most important personality in American education in his time, Lowell exerted a national influence. So appreciative of his leadership were benefactors, whether old Harvard men or not, that during his own tenure of office-twenty-four yearshe saw the endowment of his University tripled; when he retired in 1933 it stood at some thirty millions sterling. A dozen books which Lowell wrote will ensure him remembrance as an authority on government--government in America, in Great Britain, and on the Continent; but his annual reports, as president, to the Overseers of Harvard, are essays in the advance of education, not at Harvard only, but also throughout America.

Lowell died on January 6 at the age of eighty-six. Willard Connely. 